\title{
ENHANCED EX-SITU BIOREMEDIATION OF SOIL CONTAMINATED WITH PETROLEUM REFINERY WASTE EFFLUENTS BY BIOSTIMULATION THROUGH ELECTROKINETICS AND INORGANIC FERTILIZER
}

\author{
S. E. Agarry* \\ DEPARTMENT OF CHEMICAL ENGINEERING, BIOCHEMICAL AND BIOENVIRONMENTAL ENGINEERING LABORATORY, DELTA \\ STATE UNIVERSiTy, ABRAKA, OlEH CAMPUS, NIGERIA. \\ E-mail address:sam_agarry@yahoo.com
}

\begin{abstract}
Ex situ bioremediation is an attractive and often cost-effective technology for the clean-up of organics-contaminated sites; however, it often requires extended treatment time under field conditions. Electrokinetic bioremediation is an emerging technology to remediate organic-contaminated soil. Thus, the objective of this study was to investigate the feasibility and effectiveness of using electrical biostimulation processes to enhance ex-situ bioremediation of soils contaminated with organic pollutants. The effect of different applied voltages $(0.33-1.0 \mathrm{~V} / \mathrm{cm})$ as well as the effect of inorganic (NPK) fertilizer on the electrokinetic bioremediation of soil was evaluated. $A$ bench-scale uniform electrokinetic system was developed for this purpose and tested by using a sandy loam soil spiked with petroleum refinery waste effluent having total organic compound (TOC) as model organic pollutant. The results demonstrated that the application of a low direct current (voltage) could be an effective strategy to accelerate the movement and ex situ biodegradation or removal of TOC in the soil. At the application of $0.33,0.67$ and $1.0 \mathrm{~V} / \mathrm{cm}$ voltage, electricity biostimulation correspondingly and averagely remove $65.7 \%, 70 \%$ and $73.3 \%$ of TOC from soil in only 15 days without nutrient (NPK fertilizer) application; while with nutrient application, electricity biostimulation correspondingly and averagely removed $71.8 \%, 77.4 \%$ and $81.6 \%$ of TOC from soil. Thus, bioremediation of soil contaminated with petroleum refinery waste effluents can be enhanced by electrokinetics and the rate of TOC biodegradation or removal relatively increased with increased specific voltage application. The electrokinetic bioremediation of soil can further be enhanced or accelerated with the addition of nutrient in the form of nitrogen, phosphorus and potassium (NPK). Small changes in soil $\mathrm{pH}$ and/or moisture were induced by the applied electric field.
\end{abstract}

Keywords: Bioremediation; Electrokinetics; NPK Fertilizer; Refinery Waste Effluents; TOC.

\section{INTRODUCTION}

Bioremediation is an emerging technology that still has its limitations of been slow and consequently require a longer treatment time. This disadvantage may be due to physical, chemical and biological factors limitation such as nutrients, $\mathrm{pH}$, temperature, moisture, oxygen, soil properties, and contaminant concentration, number and type/species of microorganisms [1 - 4]. Thus, there is the need to increase the biodegradation rate so as to reduce the remediation time, which is referred to as enhanced bioremediation.

Enhanced bioremediation involves a broad continuum of technologies [5 - 6].These technologies might involve the addition of electron acceptors or electron donors to stimulate naturally occurring microbial populations (biostimulation) or could be the introduction of specific microbes (bioaugmentation) to enhance the biodegradation of the target pollutant [6]. Several methods to supply electron donors and acceptors into subsurface environments have been proposed including direct gas addition techniques such as, sparging of gases and membrane-supplied gas [7 - 8] and the addition of liquid and solid chemicals which could be fermentable substrates, organic and inorganic fertilizers, Fe species, oxygen and hydrogen-releasing compounds [9 - 10]. Nonetheless, these methods require periodic reapplication to sustain its amendment's effect; because chemical compounds and gases added to the subsurface easily diffuse away and are consumed through abiotic reactionsand the delivery system can be costly [11]. Therefore, a new method or approach that can provide a continuous source at a controlled rate in situ is needed. One approach has been to combine bioremediation with electrokinetics (EK) into a hybrid technology that is 
termed electrokinetic bioremediation (EKB) or electrobioremediation. The technology involves the application of direct currents in conjunction with the use of electrodes as cathodic electron sources or anodic electron sinks for microbial communities responsible for organic pollutant degradation.

EKB involves the use of bioremediation to degrade hydrocarbon contaminants and EK to mobilise them. EK mobilisation of the hydrocarbon products increases their bioavailability, thus facilitating bioremediation. The underlying mechanism or principle of EK involves the introduction of an electric current through electrodes into soil. The introduced electric current creates an electric field in the soil that leads to the mobilization and migration of contaminants via electroosmosis, electromigration, and electrophoresis [12 - 13]. These processes occur as a consequence of the resulting $\mathrm{pH}$ gradient that follows the production of hydrogen ions at the anode (acid front) and hydroxyl ions at the cathode (basic front) due to the electrolysis of water[14]. These phenomena cause changes in a number of soil properties [15]. Electrodes can offer a continuous and finely controlled supply of electron donors and acceptors to microorganisms in the subsurface [16 - 18]. Electromigration and electrophoresis result in the movement of ions, ion complexes, and charged particles, such as colloidal clay and microorganisms toward the electrode of the opposite charge. Whereas electroosmosis arises from the migration of water towards the cathode, producing an electroosmotic flow which, in turn leads to facilitates the movement of cations, hydrocarbons and microorganisms in the direction of the fluid [19].

The changes induced by the application of direct current into the soil have direct effects on the microbial activity in situ. The outer surface of microbial or bacterial cells possesses numerous chemical groups such that the changes in soil $\mathrm{pH}$ generated as a result of the direct current application allow the negatively charged microorganisms or bacteria to migrate by electrophoresis toward the anode and one-dimensional flow of pore fluid from the anode to cathode [20 - 21]. At low $\mathrm{pH}$, the bacterial membrane charge is positive and the direction of movement is toward the cathode while at a pH 7 or greater, it results in an overall negative surface potential [19]. Nonetheless, maintenance of soil $\mathrm{pH}$, between 5 and 7, is therefore necessary in order to achieve the optimum degradation of contaminants by most native soil microbes [20]. Several studies have made efforts to enhance the transport of bacteria or nutrients for effective biodegradation through the application of EKB [22 - 24].Over the last two decades, there has been increasing interest in employing electrokinetic remediation for the treatment of contaminated soil. Most of the EKR studies have mainly been for the remediation of metals $[15,25]$, radio nuclides $[15,26]$ and polar inorganic pollutants from saturated/unsaturated soil, sediments and groundwater[27] while few researches have been carried out on the electrobioremediation of soil and sediments contaminated with organic chemicals or hydrocarbons such as gasoline hydrocarbons, aromatic compounds or trichloroethylene in weak electric fields $[12-14,28-29]$. These studies seem to suggest that EKB can be effectively used for the mineralization of many organics, with lower energy expenditure. Nevertheless, EKR is still an emerging technology.

Therefore, the main aim of this study is to investigate the effectiveness of using electrical (electrokinetic) biostimulation processes to enhance ex-situ bioremediation of soils contaminated with organic pollutants while the objectives are to test the effect of different applied voltages as well as the effect of inorganic (NPK) fertilizer on the electrokinetic bioremediation of soil contaminated with petroleum refinery waste effluents. The measured parameters included the hydrogen ion concentration $(\mathrm{pH})$ values and total organic carbon (TOC) content and these parameters were measured along the length of each soil specimen. The results were analysed to assess the electrokinetic remedial efficiency.

\section{MATERIALS AND METHODS}

\subsection{Materials}

The materials used for this study consists of soil sample, autoclave, soil electrokinetic reactor (SEKR), carbon electrodes and direct current (d.c.) power supply.

\subsubsection{Experimental apparatus system}

The experimental set-up is as shown in Figure 1. It consisted of a soil electrokinetic reactor (SEKR), a pair of carbon electrodes, an electric current and voltage realtime monitoring system, and a dc power supply. The SEKR was made of Perspex with an inner size of length $30 \mathrm{~cm} \times$ width $15 \mathrm{~cm} \times$ height $15 \mathrm{~cm}$. The columnshaped carbon electrodes, length $20 \mathrm{~cm} \times$ diameter 0.5 $\mathrm{cm}$, were used to generate electric field. The power supply could provide a constant dc electric voltage in a range from 0 to $30 \mathrm{~V}$ for the electrokinetic study.

\subsection{Methods}

\subsubsection{Preparation of Soil Sample}

The soil sample for the study was collected from an agricultural farm located in Oleh, Nigeria. The soil samples were dried and sieved through an 8-mm mesh screen. The soil was characterized and some of its properties are presented in Table 1. The soil was artificially spiked with petroleum refinery liquid waste 
effluents at a target total organic compound (TOC) concentration of $156 \mathrm{~g} / \mathrm{kg}$ and thoroughly mixed together. The contaminated soil was divided into two set. One set was sterilized three times by alternatively using an autoclave $\left(121^{\circ} \mathrm{C}\right.$ for $\left.45 \mathrm{~min}\right)$ and a drier $\left(105^{\circ} \mathrm{C}\right.$ for 30 min). The two set of contaminated soil was mixed with $1500 \mathrm{ml}$ of distilled water for $30 \mathrm{~min}$ and left for two days to stabilize. The moisture content was kept at $30 \%$. The total organic compound in the soil after the addition of the refinery liquid waste effluent is $156 \mathrm{~g} / \mathrm{kg}$ soil. The microorganisms that were identified in the soil sample are mainly Pseudomonas and Bacillus species while in the refinery liquid waste effluents are Pseudomonas aeruginosa, Bacillus cereus, Clostridium butyricum and Escherichia coli.

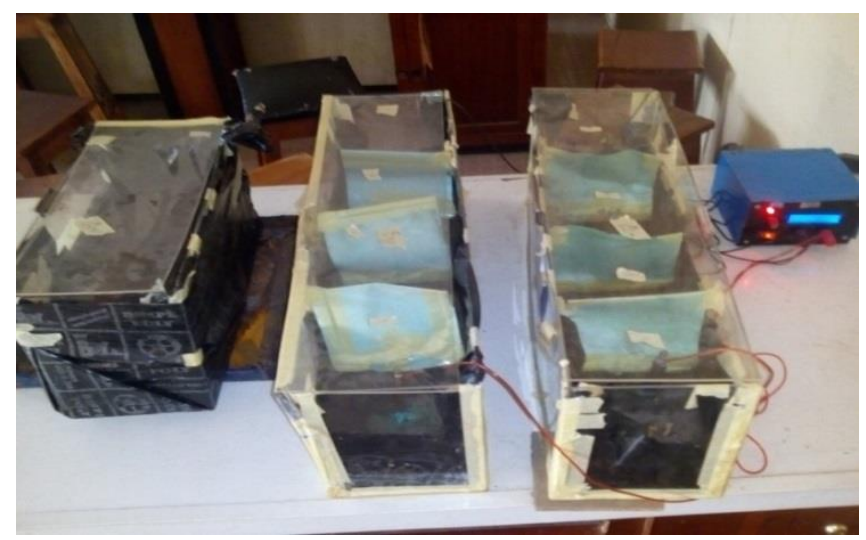

Figure 1. Electro bioremediation experimental set up

\subsubsection{Electrokinetic Experimental Procedure}

Four different SEKR labeled A, B, C and D was each filled with $8 \mathrm{~kg}$ of the moist contaminated soil. SEKR labeled A was filled with the sterilized contaminated soil used as control 1. To the contaminated soil in SEKR labeled D was added $40 \mathrm{~g}$ of inorganic NPK fertilizer which was thoroughly mixed together. Each of the SEKR was vibrated and the soil in it was compacted for $12 \mathrm{~h}$ at a pressure of $0.1 \mathrm{~kg} / \mathrm{cm}^{2}$ so as to minimize the void space in the soil. The extruded pore fluids were removed from the surface layer using white tissue paper. A soil bed with a volume of length $30 \mathrm{~cm} \times$ width $15 \mathrm{~cm} \times$ height $10 \mathrm{~cm}$ was prepared for each experiment with the two electrodes inserted into the soil at opposite sides of the bed at a distance of $15 \mathrm{~cm}$ from each other. Power supply and monitoring equipment were then connected to the electrodes. Once the assembly was completed, the SEKR was enclosed with a Perspex cover to prevent the soil bed from excessive evaporation of water and organic compounds. A constant voltage gradient of 0.33 to 1.0 $\mathrm{V} / \mathrm{cm}$ was then applied through the electrodes in one ways (bidirectional operation), and the voltage and electric current through the soil bed were recorded every $15 \mathrm{~min}$ by the real-time monitoring system. Three separate groups of tests were conducted. The first was to investigate the mobilization of TOC and the change of soil $\mathrm{pH}$. The third was to evaluate the ex situ biodegradation of TOC coupled with uniform electrokinetics. There are two control tests, SEKR labelled A with sterilized soil and electric field applied (control 1)and SEKR labelled B with unsterilized soil and no electric field applied (control 2) were run in parallel. Soil moisture was kept at 30\% $(\mathrm{m} / \mathrm{m})$ and all the tests were carried out at ambient temperature $\left(25 \pm 2^{\circ} \mathrm{C}\right)$. At the end of test, the soil bed was destructively sampled using a U-shaped sampler and a spatula to determine the TOC and soil pH. In order to reflect the spatial variation regarding the variables, sampling lines were arranged along the middle line on which the two electrodes were located, and along the sideline with a distance of $4 \mathrm{~cm}$ from the middle line. Seven spots, with distances of $1,4,7,10,13,16$ and 19 $\mathrm{cm}$ from the (initial) anode, were sampled on each line, as shown in Figure 1. In addition, soil pH was determined using a soil-to-water ratio of 1:2.5 and water content was determined using the methods described by Luo [30]. All the analysis was performed in triplicate, and the result was calculated as the average.

\subsubsection{Analysis}

A $10 \mathrm{ml}$ of $\mathrm{n}$-hexane was mixed with each samples and stirred and then allowed to stay for $4 \mathrm{~h}$ during which hexane would have evaporated leaving the refinery waste effluent for the analysis. The TOC content was determined by IR analysis of thermal induced $\mathrm{CO}_{2}$ with a TOC Analyzer Shimadzu TOC-V CSH, after heating the sample at $900^{\circ} \mathrm{C}$ with a Shimadzu Solid Sample Module. The $\mathrm{pH}$ was taken in a soil/water suspension using a $\mathrm{pH}$ meter HI 99121 by Hanna Instruments, with HI 1292D electrode for soil pH measurement.

\section{RESULTS AND DISCUSSION}

\subsection{Effect of Applied Voltage}

In this study, the actual initial content of TOC in the soil was about $156 \mathrm{mg} / \mathrm{kg}$. Mobilization of the TOC at this concentration requires desorption of the organic compounds from soil particle surface since most of the TOC are absorbed at this concentration. At the beginning of experiment, the TOC in the spiked soil was uniformly distributed. The electro-bioremediation involved the application of electricity to a homogeneous matrix composed of only sand for 15 days using specific voltage of $0.33,0.67$ and $1.0 \mathrm{~V} / \mathrm{cm}$, respectively. Sampling was done after 3, 6, 9, 12 and 15 days, taking four samples from the upper part of the cell at different distances from the electrodes. The values of the TOC concentration profiles at different specific voltage application are presented in Figure 2. 

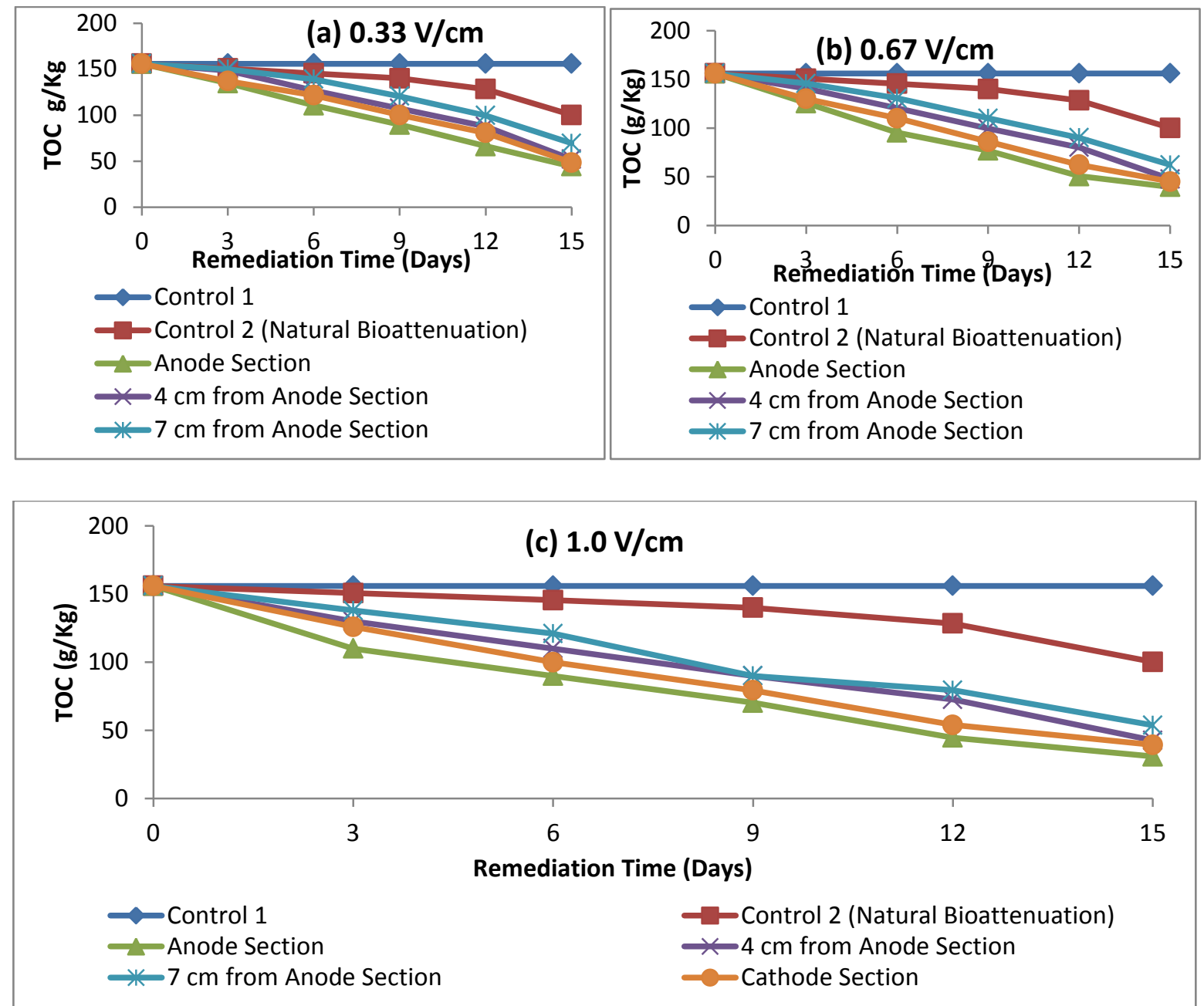

Figure 2. Effect of applied voltage on electro bioremediation of soil contaminated with petroleum refinery liquid waste effluents

As seen in Figure 2, the values of TOC decreased with remediation time with or without specific voltage applied. It is observed that there is non-uniformity of pollutant removal along the soil sample. At the application of $0.33,0.67$ and $1.0 \mathrm{~V} / \mathrm{cm}$ of voltage, the initial TOC value decreased from $156 \mathrm{~g} / \mathrm{kg}$ to the corresponding average TOC value of $44.4 \mathrm{~g} / \mathrm{kg}, 39.5 \mathrm{~g} / \mathrm{kg}$ and $30.9 \mathrm{~g} / \mathrm{kg}$ around the anode electrode $(0 \mathrm{~cm})$ and $48.4 \mathrm{~g} / \mathrm{kg}, 45 \mathrm{~g} / \mathrm{kg}$ and $39.3 \mathrm{~g} / \mathrm{kg}$ around the cathode electrode while the TOC value was $52 \mathrm{~g} / \mathrm{kg}, 47.7 \mathrm{~g} / \mathrm{kg}$ and $42.7 \mathrm{~g} / \mathrm{kg}$ at $4 \mathrm{~cm}$ and $69.3 \mathrm{~g} / \mathrm{kg}, 62.1 \mathrm{~g} / \mathrm{kg}$ and 53.7 $\mathrm{g} / \mathrm{kg}$ at $7 \mathrm{~cm}$ distances from the anode, respectively. This corresponds to an average TOC removal rate efficiency of $71.5 \%, 74.7 \%$ and $80.2 \%$ around the anode electrode $(0$ $\mathrm{cm}$ ) and $69 \%, 71.2 \%$ and $74.8 \%$ around the cathode electrode while the rate was $66.7 \%, 69.4 \%$ and $72.6 \%$ at $4 \mathrm{~cm}$ and $55.6 \%, 60.2 \%$ and $65.6 \%$ at $7 \mathrm{~cm}$ distances from the anode, respectively. Therefore, these observations indicates that the nearer to the electrode, the higher the TOC removal efficiency would be. That is, the efficiency of the biodegradation near the electrode section is higher than that far from the electrode region.
This is because, that the shorter the distance from the electrode, the stronger is the electric intensity. A similar observation has been reported [31]. Thus, TOC removal increased with increase in applied voltage. This is in agreement with the observation of Chun et al. [11] for the electrical stimulation of microbial PCB degradation in sediment. In recent years, several studies have reported that there was neither negative nor positive effects observed by applying current $\left(3.14 \mathrm{~A} / \mathrm{m}^{2}\right)$ on soil bacteria $[14,32]$. However, in this study, there are strong indications that the stronger electric field intensity near the electrodes stimulated the autochthonous microbial activities around it which thus accelerated the TOC removal or biodegradation efficiency. On the other hand, when microorganisms/bacteria were absent in the petroleum refinery waste effluents contaminated soil (control 1), the rate of TOC removal approached zero, even as direct electric field was applied. That is, no removal of TOCs was observed in sterilized control. A similar observation has been reported for polychlorinated biphenyl (PCB) [11]. Also, there was no significant difference in the TOC concentration in sample 
soil with the distances from anode. This indicated that organic compounds or hydrocarbons hardly transports in electric field. Therefore, in this study, the removal of organic pollutants from the soil might be as a result of biodegradation, volatilization and the migration of degrading bacteria. The addition of the spiked petroleum refinery waste effluents could potentially stimulate microbial degradation regardless of the application of voltage, which may explain the $35.8 \%$ removal of TOC in the soil sample with no voltage application (control 2, i.e. natural bioattenuation) (Figure 2). Despite this observed loss, greater removal or degradation of TOC was observed in SEKRs exposed to direct electric current than in the SEKR without direct current application, which suggests that the application of electric current stimulates broader and more extensive removal or degradation of TOC. This is in agreement with the observations of Niqui-Arroyo, et al. [33] for phenanthrene-contaminated soil, Li, et al. [31] for crude oil contaminated soil, Acuna, et al. [34] for hydrocarbon contaminated soil, respectively. The removal of TOCs in the SEKRs with $0.33,0.67$, and $1.0 \mathrm{~V} / \mathrm{cm}$ was statistically significant $(P=0.05)$ in comparison to the removal of TOC in SEKR without voltage application. Regarding ecotoxicity, values are presented in Table 2 . At the end of the test, a great increase in terms of $\mathrm{mg} / \mathrm{L}$ for ecotoxicity parameter was observed; that indicates a modest decrease of toxicity for bacterial action. Therefore, removal of TOC from soils in only 15 days via electrical biostimulation is promising when compared with natural bioattenuation.

\subsection{Change in Soil pH}

In addition, the results obtained at the end of the test across the soil samples revealed that the applied direct current electric field induced change in soil $\mathrm{pH}$ during the course of electrobioremediation. The dynamics of $\mathrm{pH}$ change in time and in different sections of the soil sample at different specific voltage is shown in Figure 3.

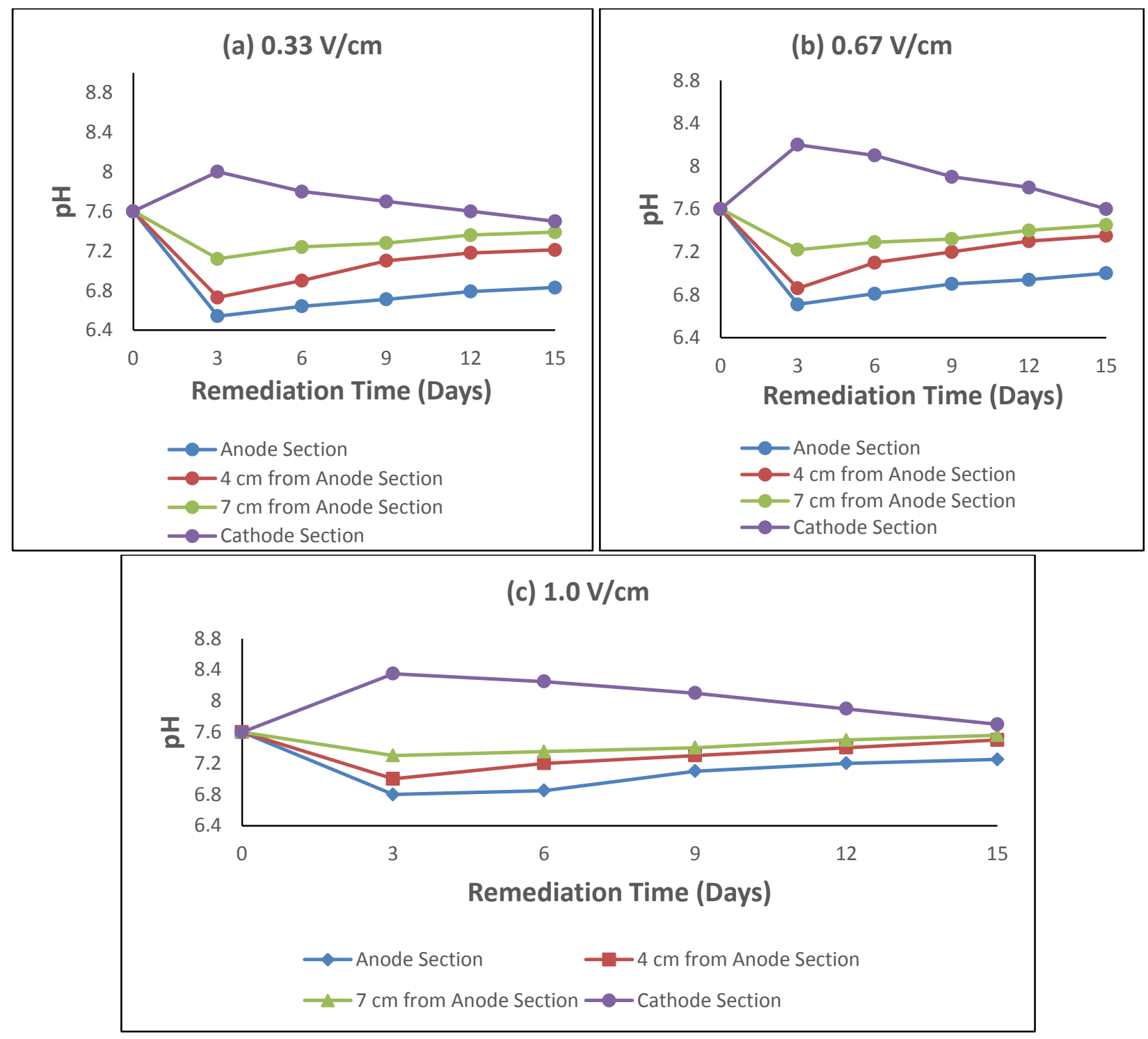

Figure 3. Variation of soil $p H$ 
At the application of $0.33,0.67$ and $1.0 \mathrm{~V} / \mathrm{cm}$ of voltage and after 3 days of remediation time, the initial $\mathrm{pH}$ generally decreased from 7.6 to the corresponding average $\mathrm{pH}$ of $6.54,6.71$ and 6.85 around or near the anode electrode $(0 \mathrm{~cm})$ and increased to $8.0,8.2$ and 8.35 around or near the cathode electrode while the $\mathrm{pH}$ value also decreased to $6.73,6.86$ and 7.0 at $4 \mathrm{~cm}$ distance and $7.12,7.2$ and 7.3 at $7 \mathrm{~cm}$ distance from the anode, respectively. Above the 3 days of remediation period, the $\mathrm{pH}$ started to increase gradually to $6.83,7.0$ and 7.25 near the anode section and began to decrease to 7.5, 7.6 and 7.7 near the cathode section while it increased to $7.21,7.35$ and 7.50 at $4 \mathrm{~cm}$ distance and 7.39, 7.45 and 7.56 at $7 \mathrm{~cm}$ distance, respectively, at the end of 15 days of remediation time. The variations in $\mathrm{pH}$ values (decrease and increase) observed around the anode section, 4 and $7 \mathrm{~cm}$ distances from anode and the cathode section may be due to the migration or movement of acidic and alkaline $\mathrm{pH}$ front from one electrode section to the other electrode section [21, 35].
More also, these observations showed that irrespective of the applied specific voltage, $\mathrm{pH}$ increased with the increase of distance from anode (conversely, $\mathrm{pH}$ decreased with increase of distance from cathode). Similar observations have been reported [12, 21, 35]. Nevertheless, the $\mathrm{pH}$ across soil bed was generally maintained between 6.8 and 7.5 which were still favourable for the autochthonous microbial activity; this was possible due to regular reversal of current intensity $[12,35]$. It was generally observed that the moisture content decreased with time at the different applied voltage and hence sterilized distilled water was added at intervals so as to maintain the moisture content at $30 \%$.

\subsection{Effect of Nutrient on Electro Bioremediation}

The effect of nutrient addition (inorganic NPK fertilizer) on electrobioremediation of soil contaminated with petroleum refinery waste effluents at different applied specific voltage is as shown in Figure 4.
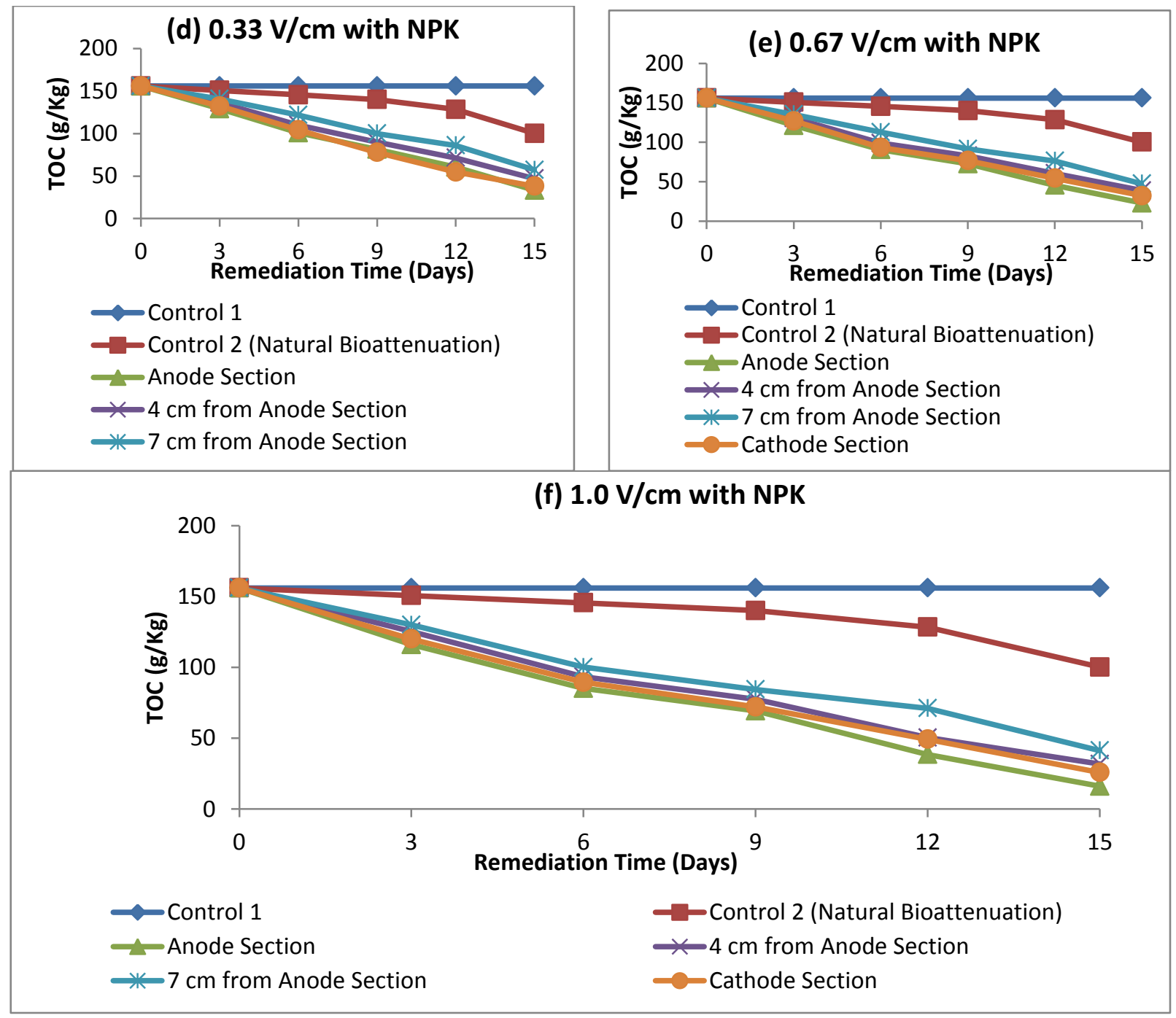

Figure 4. Effect of nutrient on electrobioremediation of soil contaminated with petroleum refinery liquid waste effluents 
Similar observations were obtained as in the case of electrobioremediation without the addition of inorganic NPK fertilizer (nutrient) (Figure 2). As shown in Figure 4 , at the application of $0.33,0.67$ and $1.0 \mathrm{~V} / \mathrm{cm}$ of voltage, the initial TOC value decreased from $156 \mathrm{~g} / \mathrm{kg}$ to the corresponding average TOC value of $33.3 \mathrm{~g} / \mathrm{kg}, 22.8 \mathrm{~g} / \mathrm{kg}$ and $16.1 \mathrm{~g} / \mathrm{kg}$ around the anode electrode $(0 \mathrm{~cm})$ and $38.2 \mathrm{~g} / \mathrm{kg}, 32.1 \mathrm{~g} / \mathrm{kg}$ and $25.9 \mathrm{~g} / \mathrm{kg}$ around the cathode electrode while the TOC value was $47 \mathrm{~g} / \mathrm{kg}, 38.7 \mathrm{~g} / \mathrm{kg}$ and $31.8 \mathrm{~g} / \mathrm{kg}$ at $4 \mathrm{~cm}$ and $57.3 \mathrm{~g} / \mathrm{kg}, 47.3 \mathrm{~g} / \mathrm{kg}$ and 41.3 $\mathrm{g} / \mathrm{kg}$ at $7 \mathrm{~cm}$ distances from the anode, respectively. This corresponds to an average TOC removal rate efficiency of $78.7 \%, 85.4 \%$ and $89.7 \%$ around the anode electrode (0 $\mathrm{cm}$ ) and $75.5 \%, 79.4 \%$ and $83.4 \%$ around the cathode electrode while the rate was $70 \%, 75.2 \%$ and $79.6 \%$ at 4 $\mathrm{cm}$ and $63.3 \%, 69.7 \%$ and $73.5 \%$ at $7 \mathrm{~cm}$ distances from the anode, respectively. The TOC removal efficiency in electro-bioremediation with the addition of inorganic NPK fertilizer was relatively higher than that in electrobioremediation without the addition of NPK fertilizer. This observation may be due to the fact that more nutrients were made available for the microorganisms and the interactions among organic pollutants, bacteria and nutrients during bioremediation were further enhanced by electrokinetics. To date, reports on the restoration of polluted soil using direct current application in conjunction with NPK fertilizer (nutrient) is still very limited. Lee, et al [36] used electrokinetics to enhance transportation of nutrient phosphorus in the petroleum polluted soil. The use of phosphate salt as nutrient to enhance electro-bioremediation of hydrocarbon contaminated soil has been reported by Acuǹa, et al. [34].

\subsection{Change in Soil pH with Nutrient Application}

Furthermore, the results obtained showed that the applied direct current with the addition of inorganic NPK fertilizer induced change in soil $\mathrm{pH}$ during the course of electro-bioremediation. The dynamics of $\mathrm{pH}$ change in time and in different sections of the soil sample at different specific voltage is shown in Figure 5.
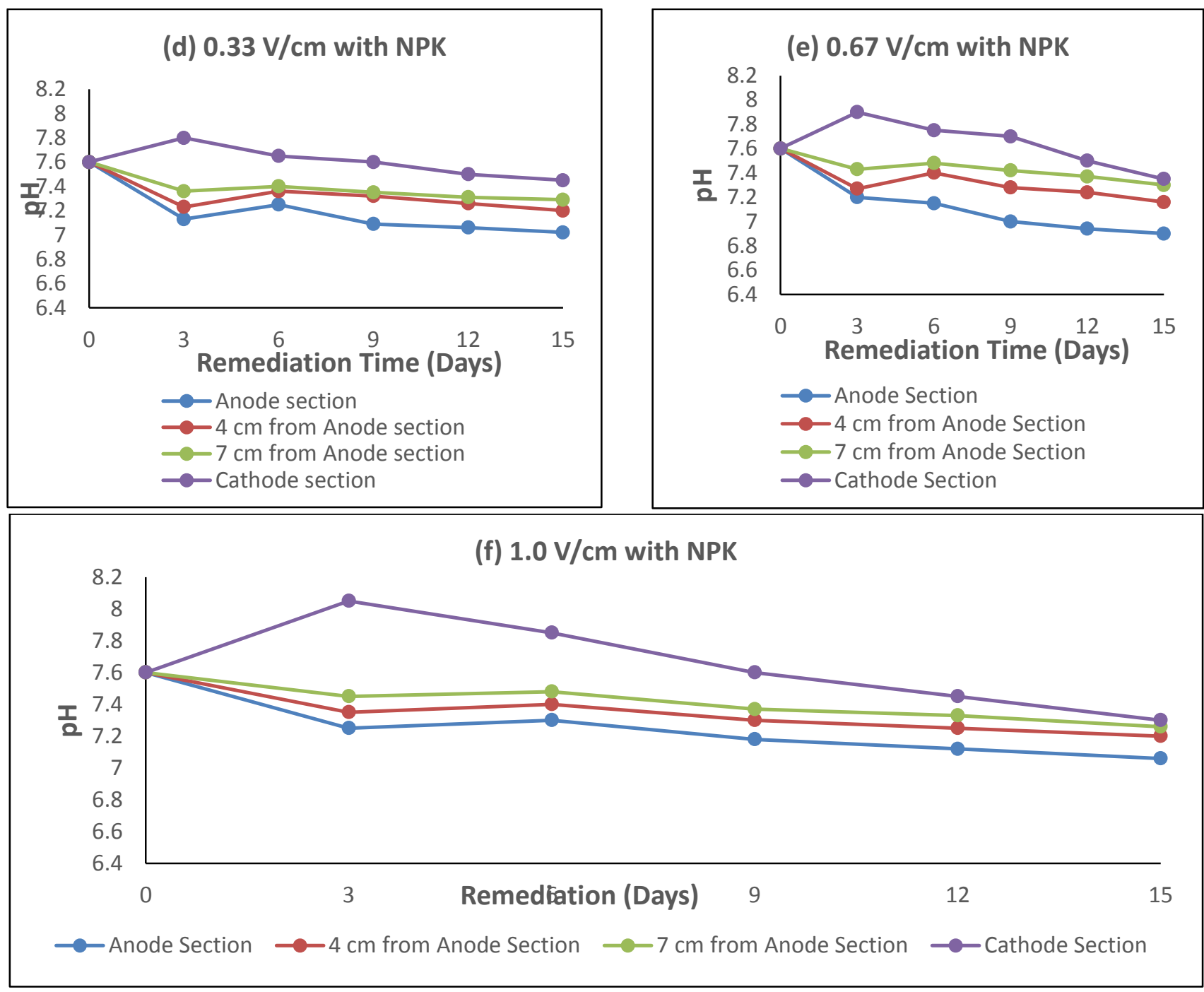

Figure 5. Variation of soil $\mathrm{pH}$ 
At the application of $0.33,0.67$ and $1.0 \mathrm{~V} / \mathrm{cm}$ of voltage and after 15 days of remediation time, the initial $\mathrm{pH}$ decreased from 7.6 to the corresponding average $\mathrm{pH}$ of $7.02,6.92$ and 7.06 around the anode electrode $(0 \mathrm{~cm})$ and 7.45, 7.35 and 7.30 around the cathode electrode while the pH value was $7.20,7.16$ and 7.20 at $4 \mathrm{~cm}$ and $7.29,7.30$ and 7.26 at $7 \mathrm{~cm}$ distances from the anode, respectively. Nonetheless, after 3 days the $\mathrm{pH}$ values near the cathode section increased to 7.8, 7.9 and 8.05 at the corresponding application of $0.33,0.67$ and $1.0 \mathrm{~V} / \mathrm{cm}$ of voltage and above this period it started to decrease. The variations of $\mathrm{pH}$ observed across the soil bed may also be due to electromigration of the acidic and alkaline front from one electrode section to the other electrode section. However, the addition of NPK fertilizer as nutrient tends to improve the soil $\mathrm{pH}$ condition as compared to soil not amended with it. Furthermore, these observations revealed that irrespective of the applied specific voltage, $\mathrm{pH}$ relatively increased with increased distance from anode (conversely, $\mathrm{pH}$ decreased with increase of distance from cathode). Similar observations have been reported [12, 30, 35].It was generally observed that the moisture content decreased with time at the different applied voltage and hence sterilized distilled water was added at intervals so as maintain the moisture content at $30 \%$.

\section{CONCLUSIONS}

This study has shown that the application of a low direct current (voltage) to soil can be an effective strategy to remediate TOC ex-situ. Specifically, at the application of $0.33, \quad 0.67$ and $1.0 \mathrm{~V} / \mathrm{cm}$ voltage, electricity biostimulation can correspondingly and averagely remove $65.7 \%, 70 \%$ and $73.3 \%$ of TOC from soil in only 15 days without nutrient (NPK fertilizer) application. While with nutrient application, electricity biostimulation can averagely remove $71.8 \%, 77.4 \%$ and $81.6 \%$ of TOC from soil in only 15 days. Thus, bioremediation of soil contaminated with petroleum refinery waste effluents can be enhanced by electrokinetics and the rate of biodegradation or removal of total organic compound present in the effluent relatively increased with increased specific voltage application. The electrokinetic bioremediation of soil can be enhanced or accelerated with the addition of nutrient in the form of nitrogen, phosphorus and potassium (NPK).The applied voltage affected the soil $\mathrm{pH}$ and moisture content.

\section{REFERENCES}

[1] Sabat'e, J., Vinas M. and Solanas A. M. Laboratory scale bioremediation experiments on hydrocarbon- contaminated soils. International Journal of Biodeterioration and Biodegradation, Vol. 54, pp. 1925. 2004,

[2] Walter M., Boyd-Wilson K. S. H., McNaughton D. and Northcott G. Laboratory trials on the bioremediation of aged pentachlorophenol residues. International Journal of Biodeterioration and Biodegradation, Vol. 55, No. 3, pp. 121-130. 2005,

[3] Atlas R.M. and Bartha R. Fate and effects of polluting petroleum in the marine environment. Residue Review, Vol. 49, No. 1, pp. 49-83 2006,

[4] Kao C. M., Chen C. Y., Chen S. C., Chien H.Y. and Chen Y. L. Application of in situ biosparging to remediate a petroleum hydrocarbon spill site: Field and microbial evaluation. Chemosphere, Vol. 70, pp. 1492-1499. 2008,

[5] Chien H. Y., Kao C. M., Jou C. J., Yang P.Y. and Huang C. C. Application of enhanced bioremediation to clean up diesel-oil contaminated soils: Laboratory microcosm study. Journal of Biotechnology, Vol. 136, pp. S682. 2008.

[6] Agarry S. E., Aremu M. O., and Aworanti O. A. Kinetic modelling and half-life study on enhanced soil bioremediation of bonny light crude oil amended with crop and animal-derived organic wastes. Journal of Petroleum and Environmental Biotechnology, Vol. 4, pp. 137. 2013.

[7] Newell C. J., Aziz C. E., Patrick E. H., Hughes J. B. and Khan T. A. Two novel methods for enhancing source zone bioremediation: direct hydrogen addition and electron accepter diversion. San Diego, CA, 2001.

[8] Ma X., Novak P. J., Clapp L.., Semmens M. J., Hozalski R. M. Evaluation of polyethylene hollow-fiber membranes for hydrogen delivery to support reductive dechlorination in a soil column. Water Research, Vol. 37, No. 12, pp. 2905-2918. 2003,

[9] Adamson D. T., McDade J. M. and Hughes, J.B. Inoculation of a DNAPL source zone to initiate reductive dechlorination of PCE. Environmental Science and Technology, Vol. 37, No. 11, , pp. 25252533. 200.

[10] Nebe J., Baldwin B.R., Kassab R. L., Nies L. and Nakatsu C. H. Quantification of aromatic oxygenase genes to evaluate enhanced bioremediation by oxygen releasing materials at a gasoline-contaminated site. Environmental Science and Technology, Vol. 43, No. 6, pp. 2029-2034. 2009.

[11] Chun C. L., Payne R.B., Sowers K.R. and May H.D. Electrical stimulation of microbial PCB degradation in sediment. Water Research, Vol. 47, , pp. 141-152. 2013.

[12] Rada E. C. and Istrate I. A. The applicability of electrical current based treatment for the remediation of different types of polluted soils contaminated by organic compounds. Journal of Bioremediation and Biodegradation, Vol. 3, , pp. 150. doi:10.4172/21556199.1000150, 2012.

[13] Gill R. T., Harbottle M. J., Smith J. W. N. and Thornton S.F. Electrokinetic-enhanced bioremediation of organic 
contaminants: A review of processes and environmental applications. Chemosphere, Vol. 107, pp. 31-42. 2014.

[14] Wick, L. Y., Shi L. and Harms H. 2007. Electrobioremediation of hydrophobic organic soil contaminants: a review of fundamental interactions. Electrochemical Acta, Vol. 52, No. 10, , pp. 3441-3448. 2007

[15] Acar Y. B. and Alshawabkeh A. N. Principles of electrokinetic remediation. Environmental Science and Technology, Vol. 27, No. 13, 1993, pp. 2638-2647.

[16] Thrash J. C. and Coates J.D. Review: direct and indirect electrical stimulation of microbial metabolism. Environmental Science and Technology, Vol. 42, No. 11, pp. 3921-3931. 2008.

[17] Aulenta F., Canosa A., Reale P., Rossetti S., Panero S. and Majone M. Microbial reductive dechlorination of trichloroethene to ethene with electrodes serving as electron donors without the external addition of redox mediators. Biotechnology and Bioengineering, Vol. 103, No. 1, pp. 85-91. 2009,

[18] Zhang T., Gannon S. M., Nevin K. P., Franks A. E. and Lovley D. R. Stimulating the anaerobic degradation of aromatic hydrocarbons in contaminated sediments by providing an electrode as the electron acceptor. Environmental Microbiology, Vol. 12, No. 4, pp. 10111020. 2010

[19] Bayer E. M. and Sloyer J. L. The electrophoretic mobility of gram-negative and cell surface properties of phenol-degrading bacteria. Applied and Environmental Microbiology, Vol. 71, pp. 423-427. 1990.

[20] Marks R. E., Acar Y. B., Gale R. J. and Ozcu-Acar E. Insitu remediation of contaminated soils by bioelectrokinetic remediation and other competitive technologies in "Bioremediation of Contaminated Soils". Edited by Wise DL, Trantolo DJ, Cichon JE, Inyang HI, Stottmeister U, Marcel Dekker, Inc., New York-Basel, Pp 579-606. 2000

[21] Luo Q., Wang H., Zhang X. and Qian Y. Effect of direct electric current on the cell surface properties of phenol-degrading bacteria. Applied and Environmental Microbiology, Vol. 71, No. 1, pp. 423427. 2005a.

[22] Kim S. J., Park J. I., Lee Y., Lee J. I. N. and Yang J. W. Application of a new electrolyte circulation method for the ex situ electrokinetic bioremediation of a laboratory-prepared pentadecane contaminated kaolinite. Journal of Hazardous Materials, Vol. 14, No. 118, pp. 171-176. 2005.

[23] Schmidt C., Barbosa M. and Almeida M. A laboratory feasibility study on electrokinetic injection of nutrients on an organic, tropical, clayey soil. Journal of Hazardous Materials, Vol. 143, No. 3, pp. 655-661. 2007.

[24] Shi L., Muller S., Harms H. and Wick L. Y. Effect of electrokinetic transport on the vulnerability of PAH- degrading bacteria in a model aquifer. Environmental Geochemistry and Health, Vol. 30, No. 2, pp. 177-182. 2008,

[25] Chung H. I. and Kang B. H. Lead removal from contaminated marine clay by electrokinetic soil decontamination. Engineering Geology, Vol. 53, pp. 139-150. 1999.

[26] Schwartz D. T., Buehler M. F., Christiansen D. X. and Davis E. J. In-situ monitoring of electrochemical transport processes in Hanford Grout Vault Soil Journal of Hazardous Materials, Vol. 55, , pp. 23-37. 1997.

[27] Maini G., Sharman A. K., Knowles C. J., Sunderland G. and Jackman S. A. Electrokinetic remediation of metals and organics from historically contaminated soil. Journal of Chemical Technology and Biotechnology, Vol. 75, 2000, pp. 657-664. 2000.

[28] Goel R. K., Flora J. R. V. and Ferry J. Mechanisms for naphthalene removal during electrolytic aeration Water Research, Vol. 37, No. 4, pp. 891-901. 2003,

[29]. Luo Q., Zhang X., Wang H. and Qian Y. Mobilization of phenol and dichlorophenol in unsaturated soils by non-uniform electrokinetics. Chemosphere, Vol. 59, pp. 1289-1298. 2005b

[30] Luo Q., Zhang X., Wang H. and Qian, Y. The use of nonuniform electrokinetics to enhance in situ bioremediation of phenol-contaminated soil. Journal of Hazardous Materials, Vol. 121, pp. 187-194. 2005c,

[31] Li T., Guo S., Wu B., Li F. and Niu Z. Effect of electric intensity on the microbial degradation of petroleum pollutants in soil. Journal of Environmental Science, Vol. 22, pp. 1381-1386.

[32] Harbottle M. J., Lear G., Sills G. C. and Thompson I.P. Enhanced biodegradation of pentachlorophenol in unsaturated soil using reversed field electrokinetics. Journal of Environmental Management, Vol. 90, No. 5, pp. 1893-1900. 2009,

[33] Niqui-Arroyo J. L., Bueno-Montes M., Posada-Baquero R. and Ortega-Calvo J. J. Electrokinetic enhancement of phenanthrene biodegradation in creosote-polluted clay soil. Environmental Pollution, Vol. 142 No. 2, pp. 326-332.

[34] Acuña A.J., Tonín N.L., Pucci G.N., Wick L. and Pucci O.H. Electrobioremediation of an unsaturated 2006,soil contaminated with hydrocarbon after land farming treatment. Portugaliae Electrochimica Acta, Vol. 28, No. 4, pp. 253-263. 2010,

[35] Khodadadi A., Yousefi D., Ganjidoust H. and Yari M. Bioremediation of diesel-contaminated soil using Bacillus sp. (strain TMY-2) in soil by uniform and nonuniform electro kinetic technology field. Journal of Toxicology and Environmental Health Science, Vol. 3, No. 15, 2011, pp. 376-384. 2011.

[36] Lee G., Ro H., Lee S. and Lee S. Electrokinetically enhanced transport of organic and inorganic phosphorus in a low permeability soil. Geoscience Journal, Vol. 10, pp. 85-89. 2006. 